\title{
PENINGKATKAN KEAKTIFAN BELAJAR EKONOMI SISWA KELAS XI MELAUI MEDIA VIDIO SCRIBE PADA PEMBELAJARAN DARING DI SMA NEGERI 7 BALIKPAPAN
}

\author{
Kiki Tri Setia Mei Lestari ${ }^{1}$, Prita Indriawati ${ }^{2}$ \\ Universitas Balikpapan ${ }^{1}$, Universitas Balikpapan ${ }^{2}$ \\ pos-el: meilestarikiki@gmail.com ${ }^{1}$, prita.indria@gmail.com²
}

\begin{abstract}
ABSTRAK
Keaktifan belajar siswa kelas XI MIPA 1 di SMA Negeri 7 Balikpapan Tahun Ajaran 2020/2021. Adapun tujuan dilakukannya penelitian ini yakni untuk mengetahui bagaimana keaktifan belajar ekonomi siswa kelas XI MIPA 1 di SMA Negeri 7 Balikpapan dengan jumlah siswa sebanyak 36 orang. Penelitian ini merupakan penelitian tindakan kelas (PTK) yang dilakukan peneliti sebanyak dua siklus. Pada setiap siklus terdiri dari empat tahap yakni : (1) Perencanaan tindakan, (2) Pelaksanaan tindakan, (3) Observasi, (4) Refleksi. Teknik pengumpulan data pada penelitian ini melalui wawancara, angket, observasi dan dokumentasi. Hasil penelitian menunjukkan bahwa terjadi peningkatan keaktifan belajar siswa setelah menggunakan media pembelajaran Video Scribe pada pembelajaran daring. Dengan persentase siklus I sebesar $67 \%$ dan mengalami peningkatan pada siklus II dengan persentase sebesar $80 \%$ data ini diperoleh sesuai dengan indikator keaktifan belajar siswa.
\end{abstract}

Kata Kunci : Keaktifan Siswa, Media Video Scribe, Pembelajaran Daring.

\begin{abstract}
Learning activeness of class XI MIPA 1 students at SMA Negeri 7 Balikpapan for the 2020/2021 academic year. The purpose of this research is to find out how active learning economics class XI MIPA 1 students at SMA Negeri 7 Balikpapan with a total of 36 students. This research is a classroom action research (PTK) which was conducted by researchers in two cycles. Each cycle consists of four stages, namely: (1) Planning the action, (2) Execution of the action, (3) Observation, (4) Reflection. Data collection techniques in this study through interviews, questionnaires, observation and documentation. The results showed that there was an increase in student learning activeness after using the Video Scribe learning media in online learning. With the percentage of the first cycle of $67 \%$ and an increase in the second cycle with a percentage of $80 \%$, this data was obtained in accordance with the indicators of student learning activeness.
\end{abstract}

Keywords: Student Activeness, Video Scribe Media, Online Learning.

\section{PENDAHULUAN}

Pendidikan merupakan upaya untuk membentuk generasi penerus bangsa yang berkualitas, pendidikan juga mempunyai peranan yang penting bagi kehidupan. Kualitas pendidikan yang tinggi diperlukan untuk mendukung manusia cerdas dan berkualitas sehingga mampu bersaing di era globalisasi. Dengan adanya pendidikan akan membentuk karakter, pengetahuan ilmu, dan mental seorang anak yang akan tumbuh dewasa untuk memberikan pengaruh terhadap lingkungannya.

Dalam proses pembelajaran siswa sebagai subjek belajar harus aktif dalam proses pembelajaran. Menurut Sudjana (2010) keaktifan belajar merupakan partisipasi siswa dalam kegiatan belajar. Keaktifan siswa membuat proses pembelajaran berjalan sesuai dengan 
rencana tujuan pembelajaran yang disusun oleh guru. Keaktifan ini dapat berbentuk aktivitas individu siswa ataupun aktivitas kelompok, maka dari itu keaktifan siswa dalam proses pembelajaran sangat diperlukan untuk memperoleh hasil pembelajaran. Proses pembelajaran merupakan bagian dari tujuan pendidikan, yang saling berhubungan erat sebagai interaksi guru dan siswa. Dalam proses pembelajaran terdapat berbagai unsur-unsur pembelajaran antara lain tujuan dan materi pembelajaran, sarana prasarana, kondisi belajar, media pembelajaran, metode pembelajaran serta evaluasi. Unsur pembelajaran ini dapat dicapai dengan proses belajar mengajar yang efektif dan efisien. Pemilihan media pembelajaran yang tepat dan menarik serta mampu memberikan pemahaman yang bermakna bagi siswa juga merupakan salah satu upaya untuk mencapai kondisi tersebut.

Proses pembelajaran dengan menggunakan media akan membuat jarak jauh. Media daring ini dapat memberikan kontribusi untuk tercapainya proses kegiatan belajar mengajar, dan memberikan motivasi belajar sehingga siswa tidak menjadi bosan dalam proses kegiatan belajar mengajar. Dalam proses pembelajaran daring guru dan siswa dapat berinteraksi menggunakan aplikasi di smartphone antara lain aplikasi Google Classrom, Google Meet dan WhatsApp .

Berdasarkan pengalaman penelitian dalam melaksanakan proses pembelajaran banyak permasalahan yang peneliti temui seperti, keaktifan siswa di kelas XI MIPA 1 pada mata pelajaran ekonomi ketika proses pembelajaran daring sangat rendah. Siswa cenderung tidak memberikan respons ketika guru memulai pembelajaran atau ketika pembelajaran berlangsung. Karena keaktifan merupakan salah satu aktivitas belajar mengenai pemahaman atau persoalan pelajaran lebih menarik perhatian siswa, bahan belajar ini juga lebih mudah untuk dipelajari. Maka dari beragam media pembelajaran salah satunya yaitu media Video Scribe, dalam proses pembelajaran melalui media ini siswa diharapkan dapat aktif terhadap interaksi dan komunikasi. Menurut Octavianigrum (2016) Video Scribe merupakan Software yang bisa digunakan dalam membuat desain animasi berlatar putih yang sangat mudah dan menarik. Penyampaian materi dengan media video cenderung lebih mudah, Pembelajaran pada masa pandemi covid 19 saat ini perlu adanya penerapan media yang mampu meningkatkan keaktifan belajar siswa. Pembelajaran juga dilakukan secara daring (online) Menurut M.Romli (2012) daring merupakan format media yang bisa di akses melalui jaringan internet yang terdapat teks, suara, foto, serta video, sebagai sarana komunikasi massa

secara

yang siswa hadapi dalam proses pembelajaran. Siswa di tuntut untuk terlibat secara aktif dalam proses pembelajaran, keaktifan siswa bisa diamati jika ada keterlibatan siswa ketika aktivitas belajar berlangsung. Dan dapat dilihat bahwa keaktifan siswa kelas XI di SMA 7 Balikpapan ini masih rendah, keadaan ini tidak lepas dari model pembelajaran yang digunakan kurang kreatif dan inovatif. Keaktifan siswa dalam proses pembelajaran daring ini dapat menggunakan media Google Meet sebagai salah satu media alternatif yang bisa membantu proses pembelajaran jarak jauh, akan tetapi peneliti menemukan suatu kendala pada saat menjalankan pembelajaran dengan menggunakan media Google Meet, kendala itu terjadi disebabkan oleh kondisi siswa yang tidak memiliki kuota/ paket data untuk mengakses Google Meet, kondisi jaringan yang 
susah serta kendala kepemilikan smartphone (rusak atau tidak mempunyai). Begitu pun dari hasil wawancara dengan guru pamong $\mathrm{Hj}$. Nurlaila, S. Pd. bahwa proses pembelajaran daring menggunakan media Google Meet kurang efektif melihat kondisi jaringan serta keterbatasan kuota yang dimiliki siswa, karena media Google Meet ini banyak menggunakan kuota sehingga muncul pula keluhan yang di alami oleh siswa. Maka dari beberapa kendala yang di alami, peneliti harus menentukan model pembelajaran yang kreatif dan inovatif dan mudah di akses sehingga dapat meningkatkan keaktifan siswa pada proses pembelajaran daring dengan menggunakan media Video Scribe.

Dari penelitian Hesti Astuti (2019), dengan judul "Penerapan Media Pembelajaran Berbasis Video Scribe untuk Meningkatkan Keaktifan Belajar Siswa dalam Pembelajaran Akuntansi Keuangan Kelas XI di SMK Batik I Surakarta", menyatakan bahwa keaktifan siswa meningkat dengan menggunakan media Video Scribe. Selanjutnya Wahyu Romadani (2019), berjudul "Penerapan Media Pembelajaran Berbasis dengan Aplikasi Video Scribe untuk Meningkatkan Keaktifan Belajar Siswa Kelas XI IPS pada Mata Pelajaran Ekonomi SMA Muhammadiyah 2 Surakarta", Tahun Pelajaran 2018/2019, menyatakan peningkatan dengan menggunakan media Video Scribe pada keaktifan belajar siswa.

Dengan melihat kondisi pembelajaran daring yang terjadi akibat pandemi COVID 19 maka peneliti tertarik untuk melakukan penelitian dengan judul "Peningkatan keaktifan Belajar Ekonomi Siswa Kelas XI Melalui Media Video Scribe pada Pembelajaran Daring di SMA Negeri 7 Balikpapan Tahun Ajaran 2020/2021".

\section{METODE PENELITIAN}

Penelitian ini merupakan Penelitian Tindakan Kelas (PTK). Peneliti berperan aktif sejak penyusunan proposal penelitian, pelaksanaan penelitian, hingga penyusunan laporan. Tempat Penelitian Tindakan Kelas (PTK) ini berlokasi di SMA Negeri 7 Balikpapan. Letak sekolah berada di Lamaru di Jalan Mulawarman Gang Handayani No.63 RT.20, Lamaru, Balikpapan Timur, Kota Balikpapan, Kalimantan Timur, 76116. Waktu penelitian ini dilaksanakan pada semester ganjil tahun 2020/2021 melalui daring pada pembelajaran Ekonomi, yang bertepatan pada bulan September 2020 hingga bulan Desember 2020.

Subjek dari penelitian ini adalah siswa laki-laki dan perempuan kelas XI MIPA 1 di SMA Negeri 7 Balikpapan yang berjumlah 36 orang dan terdiri dari 9 orang siswa laki-laki dan 27 orang siswa perempuan. Peneliti memilih Kelas XI MIPA 1 sebagai Subyek penelitian karena kelas tersebut di pandang tepat terdapat beberapa masalah yang dapat dijadikan dasar oleh peneliti yaitu seperti rendahnya keaktifan belajar siswa dalam mengikuti pembelajaran daring pada mata pelajaran ekonomi, beberapa penyebab dari timbulnya masalah tersebut ialah model pembelajaran yang masih belum inovatif sehingga siswa kurang antusias dan kurang memahami materi yang disampaikan. Objek penelitian ini saling berkaitan dengan rumusan masalah yang ada yaitu “ Peningkatan Keaktifan Belajar Ekonomi Siswa Kelas XI Melalui Media Video Scribe Pada Pembelajaran Daring di SMA 7 Balikpapan".

Langkah-langkah dari penelitian ini merupakan bagian dari proses yang dilaksanakan dalam penelitian. Sebelum melakukan penelitian, peneliti melakukan observasi awal atau orientasi untuk mengetahui gambaran 
pelaksanaan pembelajaran di dalam kelas, keadaan di dalam kelas dan mengidentifikasi kemungkinan masalah atau kendala yang akan muncul.

Prosedur PTK menggunakan media Video Scribe untuk meningkatkan keaktifan belajar siswa pada mata pelajaran Ekonomi di kelas XI MIPA 1 SMA Negeri 7 Balikpapan 2020 adalah sebagai berikut:

\section{Sikus I}

\section{a) Observasi Permasalahan}

Sebelum melaksanakan perencanaan peneliti terlebih dahulu melakukan pengamatan untuk melihat permasalahan yang terjadi di kelas MIPA 1. Permasalahan dapat diketahui dari kegiatan-kegiatan yang dilakukan pada saat sebelum siklus dimulai. Siklus I ini terdiri dari 3 rangkaian yaitu:

\section{Perencanaan I}

Penelitian ini dilakukan dalam beberapa tahap pelaksanaan tindakan sebagai berikut:

1) Menyusun Rencana Pelaksanaan Pembelajaran (RPP).

2) Menyiapkan media pembelajaran.

3) Membuat lembar kerja siswa untuk melihat bagaimana kondisi keaktifan belajar siswa.

4) Membuat lembar kisi-kisi angket keaktifan belajar siswa

\section{Pelaksanaan I}

1) Pada kegiatan pendahuluan, hal yang dilakukan adalah membuat informasi melalui Google Classroom dan whatapp grup untuk melakukan pengisian daftar hadir siswa dan bergabung dalam pertemuan pembelajaran melalui Google Meet.

2) setelah siswa masuk keseluruhan ke Google Meet, guru memulai pembelajaran dengan mengucapkan salam, berdoa dan mengecek kehadiran siswa kembali secara manual.
3) Siswa merespon dengan mengucapkan salam dan mulai berdoa.

4) Guru bertanya mengenai materi sebelumnya.

5) Guru menyampaikan tujuan pembelajaran.

6) Siswa menerima informasi.

7) Guru meminta siswa untuk membaca materi yang ditampilkan dilayar secara bergantian.

8) Guru memberikan angket keaktifan belajar siswa.

9) Guru bersama siswa menyimpulkan materi pembelajaran.

\section{Observasi I}

Observasi dilakukan saat tindakan pembelajaran dilakukan. Observasi difokuskan untuk melihat antusias siswa dalam proses pembelajaran dengan menggunakan media Google Meet. Peneliti bertujuan untuk melihat tinggi rendahnya antusias belajar siswa belajar yang dicapai pada materi kebijakan moneter dan kebijakan fiskal.

\section{Refleksi I}

Refleksi dilakukan berdasarkan hasil analisis data dari hasil observasi maupun data evaluasi. Refleksi dilakukan dengan tujuan untuk mengetahui keaktifan belajar siswa dengan menggunakan media Google Meet, sebagai dasar membuat kesimpulan, serta melihat kesesuaian yang dicapai dengan yang diinginkan dalam pembelajaran untuk menemukan kelemahan-kelemahan dan Kendalakendala dalam pembelajaran. tentang kebijakan moneter dan kebijakan moneter untuk selanjutnya diperbaiki pada siklus II.

Setelah siklus I dilakukan belum mendapat hasil yang diinginkan. Maka dalam hal ini dilanjutkan pada siklus II dengan tujuan yang sama. 


\section{Siklus II}

\section{a) Observasi Permasalahan}

Masih ada kekurangan yang ditemukan pada Siklus I sehingga perlu adanya rencana dan pelaksanaan Siklus II. Pelaksanaan perbaikan ini tetap menggunakan media Video Scribe. Rangkaian perbaikan di siklus II ini terdiri :

\section{Perencanaan II}

Dari hasil evaluasi dan analisis serta refleksi yang dilakukan pada pelaksanaan tindakan siklus I dengan menemukan permasalahan baru yang muncul pada tindakan siklus sebelumnya akan diperbaiki di siklus ke II, dengan kegiatan yang dilakukan dalam perencanaan yang sama yaitu:

1) Menyusun Rencana Pelaksanaan Pembelajaran (RPP).

2) Menyiapkan bahan ajar atau sumber materi.

3) Menyiapkan media pembelajaran yaitu Video Scribe.

4) Membuat kisi-kisi angket untuk melihat keaktifan belajar siswa.

\section{Pelaksanaan II}

Kegiatan yang dilakukan pada tahap pelaksanaan ini adalah melaksanakan pembelajaran sesuai dengan rencana Pembelajaran yang telah dipersiapkan yaitu:

1) Pada kegiatan pendahuluan, hal yang dilakukan adalah membuat informasi melalui whatapp grup dan Goggle Clasroom untuk melakukan pengisian daftar hadir.

2) Setelah siswa mengisi daftar hadir, guru memulai pembelajaran dengan memberikan Video Scribe berkaitan dengan materi kebijakan moneter dan kebijakan fiskal.

3) Siswa mendengarkan dan memperhatikan Video Scribe yang diberikan.

4) setelah selesai pemutaran Video Scribe, guru bertanya mengenai kejelasan penyampaian materi dan memberikan pertanyaan mengenai materi.

5) Siswa merespon pertanyaan dari guru berkaitan dengan materi.

6) Guru bersama siswa menyimpulkan materi pembelajaran.

7) Di akhir pembelajaran guru memberikan angket keaktifan belajar siswa.

8) Guru menutup pembelajaran dengan berdoa dan memberikan salam.

\section{Observasi II}

Observasi dilakukan saat tindakan pembelajaran dilakukan. Pengamatan difokuskan untuk melihat keaktifan belajar siswa dalam proses pembelajaran dengan menggunakan Media Video scribe. Peneliti bertujuan untuk melihat tinggi rendahnya keaktifan belajar siswa yang dicapai.

\section{Refleksi II}

Pada tahap ini peneliti melakukan refleksi terhadap pelaksanaan siklus II dan menganalisis serta membuat kesimpulan atas pelaksanaan media Video Scribe dalam upaya meningkatkan keaktifan belajar siswa pada pembelajaran Ekonomi materi kebijakan moneter dan kebijakan fiskal, pada tahap refleksi ini diharapkan tidak ada lagi kesulitan siswa dalam memahami materi dalam Kegiatan pembelajaran Ekonomi. Jika masalah terselesaikan maka dapat di artikan bahwa penelitian berhasil.

\section{Indikator Penilaian Keaktifan Belajar Siswa}

Skala yang di jadikan tolak ukur keberhasilan pada penelitian tindakan kelas berupa kriteria kategori keaktifan belajar siswa menurut Narita Dyah Arini,. dkk (2019) sebagai berikut 


\begin{tabular}{ll|}
\hline \multicolumn{1}{|c|}{ Kategori } & Skor Skala \\
\hline Sangat Rendah & $\mathbf{1 6 \%}-\mathbf{3 1 \%}$ \\
\hline Rendah & $\mathbf{3 2 \%}-\mathbf{4 7 \%}$ \\
\hline Sedang & $\mathbf{4 8 \%}-\mathbf{6 3 \%}$ \\
\hline Tinggi & $\mathbf{6 4 \%}-\mathbf{7 9 \%}$ \\
\hline Sangat Tinggi & $\mathbf{8 0 \%}-\mathbf{1 0 0 \%}$ \\
\hline $\begin{array}{l}\text { Gambar 6. Skala } \\
\text { Belajar Siswa. }\end{array}$
\end{tabular}

\section{Teknik Analisis Data}

Pengelolaan data pada siklus dilakukan untuk mengetahui berhasil tidaknya tindakan yang dilakukan dalam proses pembelajaran di penelitian ini. Analisis data dalam penelitian ini dilakukan dengan cara peneliti melakukan refleksi hasil observasi terhadap proses pembelajaran ekonomi materi kebijakan moneter dan kebijakan fiskal di kelas XI MIPA 1 SMA Negeri 7 Balikpapan dengan media pembelajaran Video Scribe.

Langkah analisis data yang digunakan dalam penelitian ini adalah analisis deskripsi dengan membandingkan nilai antar siklus.

Berikut penjelasan mengenai langkah-langkah menganalisis data, yaitu :

1) Analisis Keaktifan Belajar
Siswa.
Untuk menganalisis persentase Keaktifan belajar siswa data diperoleh dari angket Keaktifan belajar yang telah diisi oleh siswa. Indikator pada angket tersebut telah disesuaikan pada indikator Keaktifan belajar siswa. Data-data tersebut dianalisis sebagai berikut:

$P=\sum$ Siswa yang memenuhi indikator keaktifan Belajar

$\overline{\text { ¿siswa yang mengisiangke }} \times 100 \%$

2) Grafik

Grafik digunakan untuk menggambarkan peningkatan dan persentase keaktifan belajar siswa dengan media Video Scribe pada pembelajaran daring.

\section{HASIL DAN PEMBAHASAN}

Penelitian ini dilakukan dalam 2 siklus, setiap siklus terdiri dari 2 pertemuan. Pada Pelaksanaan siklus I dilaksanakan pada 02 November 2020 dan 09 November 2020, sedangkan siklus II dilaksanakan pada 16 November 2020 dan 23 November 2020. Peneliti melakukan penelitian untuk meningkatkan keaktifan belajar siswa pada pembelajaran online di siswa kelas XI MIPA 1 di SMA Negeri 7 Balikpapan melalui media pembelajaran Video Scribe sehingga siswa dapat aktif dalam pembelajaran ekonomi.

Berdasarkan pengamatan dari guru mata pelajaran ekonomi SMA Negeri 7 Balikpapan masih banyak siswa yang belum memenuhi kriteria keaktifan, maka dari itu harus dilakukan tindakan untuk meningkatkan keaktifan belajar siswa. Dalam proses pembelajaran dibagi menjadi 3 yaitu kegiatan awal, inti, dan akhir.

1. Pembahasan Keaktifan Belajar

Siswa Siklus I

Hasil perhitungan angket yang di tinjau dari indikator keaktifan belajar siswa dalam pelajaran ekonomi menggunakan media Video Scribe pada pembelajaran daring.

Persentase hasil capaian tiap indikator keaktifan belajar siswa pada siklus I berdasarkan observasi yang disajikan dalam bentuk diagram sebagai berikut :

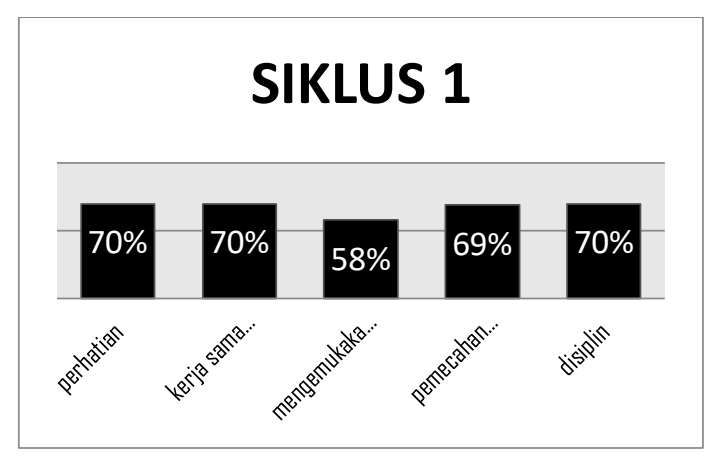

Gambar 7. Diagram Siklus 1 
Berdasarkan tindakan yang di lakukan pada siklus I yang terdapat pada diagram di atas belum adanya peningkatan dan masih tergolong rendah pada kriteria keaktifan dikarenakan belum menggunakan media Video Scribe. Adapun hasil dari penelitian (Narita Dyah Airini,. dkk, 2019) bahwa hasil dari persentase tindakan siklus I mencapai $72,44 \%$.

Dari hasil penelitian tindakan siklus I ini yang menunjukkan persentase sebesar $67 \%$ tergolong rendah dan belum mencapai target yang di inginkan. Sehingga penelitian ini akan dilakukan tindakan selanjutnya yaitu siklus II.

\section{Pembahasan Keaktifan Belajar}

Siswa Siklus II

Berdasarkan hasil perhitungan angket yang di tinjau dari indikator keaktifan belajar siswa dalam pelajaran ekonomi pada pembelajaran daring menggunakan media Video Scribe.

Persentase hasil tiap indikator keaktifan belajar siswa pada siklus II berdasarkan data angket yang di sajikan dalam bentuk diagram sebagai berikut :

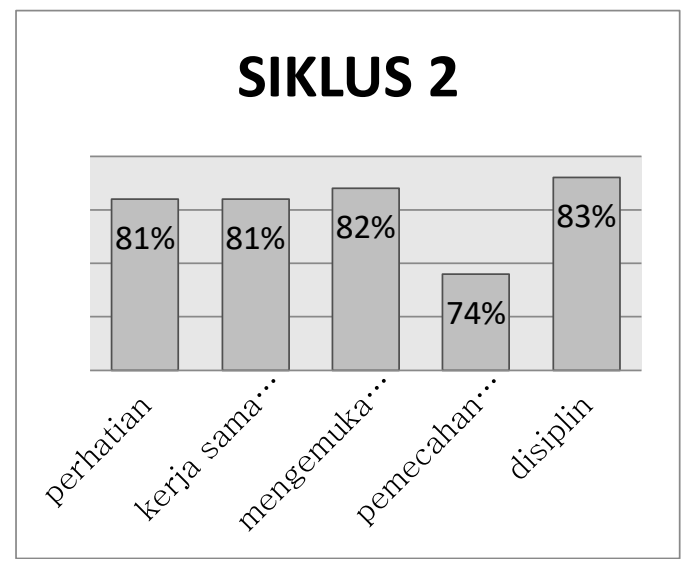

Gambar 8. Siklus II

Berdasarkan hasil penelitian yang di dapat dari tindakan pada siklus II ini menunjukkan persetase sebesar $80 \%$ dan tergolong tinggi menurut skala kriteria keaktifan belajar siswa. Adapun hasil dari penelitian sebelumnya (Narita Dyah Airini,. dkk, 2019) menujukkan persentase pada tindakan siklus II sebesar 81,29\%.

Karena terjadinya peningkatan keaktifan belajar siswa pada siklus II yang dilakukan tindakan dalam proses pembelajaran dengan menggunakan media Video Scribe maka peneliti tidak melakukan tindakan selanjutnya.

3. Perbandingan Siklus I dan II

Dapat diketahui bahwa keaktifan belajar siswa pada mata pelajaran ekonomi materi kebijakan moneter dan kebijakan fiskal dalam perhitungan angket mengalami peningkatan yang signifikan. Nilai rata-rata hasil angket pada indikator keaktifan belajar siswa pada siklus I dengan menggunakan media Google Meet terbilang rendah yaitu sebesar $67 \%$, sedangkan pada siklus II dengan media Video Scribe rata-rata dari indikator keaktifan belajar siswa pada perhitungan angket mengalami peningkatan sebesar $80 \%$ terbilang kriteria sangat tinggi pada peningkatan keaktifan belajar siswa dari rata-rata perhitungan angket pada siklus I dan siklus II dapt digambarkan dengan diagram grafik sebagai berikut :

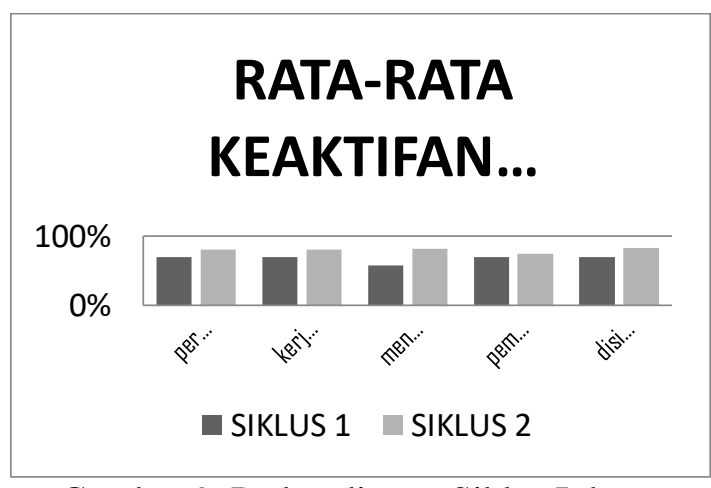

Gambar 9. Perbandingan Siklus I dan Siklus II

Selain dari angket hasil temuan dari perbandingan siklus I dan siklis II ini juga mengembangkan dari hasil dokumentasi yang di dapatkan pada saat proses pembelajaran berlangsung. 
Berdasarkan hasil pengamatan yang peneliti dapat dalam melakukan observasi dalam penelitian ini menyatakan bahwa pada Siklus I dan Siklus II mengalami peningkatan dengan menggunakan media pembelajaran yang berbeda yaitu pada Siklus I menggunakan media pembelajaran Google Meet dan pada Siklus II menggunakan media pembelajaran Video Scribe. Selain dari angket hasil temuan dari perbandingan siklus I dan siklis II ini juga mengembangkan dari hasil dokumentasi yang di dapatkan pada saat proses pembelajaran berlangsung.

\section{KESIMPULAN}

Dari uraian penelitian tindakan kelas (PTK) pada pembahasan di bab sebelumnya dengan judul " Peningkatan Keaktifan Belajar Siswa Kelas XI MIPA 1 Melalui Media Video Scribe Pada Pembelajaran daring di SMA Negeri 7 Balikpapan" . berdasarkan hasil penelitian tindakan kelas (PTK) ini dapat di ambil kesimpulan yakni tindakan di lakukan dengan dua siklus (siklus I dan siklus II), dengan menggunakan media Video Scribe untuk meningkatkan hasil belajar siswa dengan persentase peningkatan dari angket siswa pada siklus I yang masih tergolong rendah dengan persentase siklus I $67 \%$ dan pada siklus II meningkat sebesar $80 \%$ serta telah memenuhi kriteria sangat tinggi pada siklus II ini.

\section{DAFTAR PUSTAKA}

Ami, Alimah. (2010). Peningkatan Keaktifan Siswa Dalam Pembelajaran Matematika Melalui Model Pembelajaran Van Hile dan Make A Match Pada Siswa Kelas VII A SMP 1 Sambirejo. Skripsi. Surakarta: FKIP_UMS
Arini,Narita Dyah. dkk. (2019). Efektifitas Think Pair Share Berbasis Saintifik Berbantuan Media Video Scribe Untuk Meningkatan Keaktifan Peserta Didik.

Kristin. (2017). Penerapan Model Pembelajaran Temas Gamers Tournament Untuk Meningkatakan Keaktifan dan Hasil Belajar IPA.

Kuntarto,. E. (2017). Keefektifan Model Pembelajaran Daring Dalam Perkuliahan di Perguruan Tinggi.

Martinis,. Yamin. (2017). Kiat Membelajarkan Siswa. Jakarta.

Molinda,. M. (2005). Intructional Technology And Media For Learning New Jersey Columbus. Ohio

M, Romli. (2012). Jurnalistik Online : Panduan Mengelola Media. Bandung : Nuansa Cendekia.

Muah, Tri. (2015). Penggunaan Model Pembelajaran Program Based Intruction (PBI) untuk Meningkatkan Keaktifan Sdan Hasil Belajar Matematika Siswa Kelas 9B SemesterGasal Tahun Pelajaran 2014/2015 SMP Negeri 2 TuntangSemarang.

Nazir,. (2014). Metode Penelitian . Bogor. Ghalia Indonesia

Octavianingrum. (2016). Pembangunan Media Audio Visual Sprakol Video Scribe dalam PembelajaranMengelola Pertemuan/ Rapat di Lembaga Pendidikan Profesi (LPP) IPMI Kusuma Bangsa 
Surakarta Jurusan https://www.stitalkifayahriau.ac.id/pene

Administrasi Perkantoran.

Pamungkas,. Aan Subhan,. dkk. (2018)

Vidio Pembelajaran Berbasi

Sparkol Video Scribe : Inovasi

Pada Perkuliahan Sejarah Matematika.

Sadikin, Ali. (2020). Pembelajaran

Daring di Tengah Wabah Covid -19 .

rapan-sistem-pembelajarandaring-dan-luring-di-tengahpandemi-covid-19/_pada tanggal 23 November pukul 20.00

https://goeroendeso.wordpress.com/201 8/03/18/mengenal-siklusdalam-penelitian-tindakankelas/ pada tanggal 23 November 2020 pukul 22.22.

Sudjana, Nana. (2010). Dasar-dasar Siswa Aktif Dalam Proses Belajar Mengajar. Bandung. Sinal Algersindo.

Sugiyono. (2010). Metode Penelitian Pendidikan Kuantitatif, Kualitatif dan $R \quad \& \quad D$. Bandung. Alfabeta.

Sumarso. (2018). Mengenal Siklus Pada Penelitian Tindakan Kelas.

Yatim. Riyanto. (2010).Metodelogi Penelitian pendidikan. Surabaya. Penerbit SIC.

Zulafwan, Wilyansya. (2020). Pemanfaatan Aplikasi Video Scribe dan 3D Based Sebagai Media Pembeajaran Untuk Guru Pada SMK N 2 Pekan Baru.

http://pgdikmen.kemdikbud.go.id/readnews/pembelajaran-daringmemberikan-banyak-manfaat diakses pada tanggal 20 November 2020 Pukul 19.35 